\title{
PROSPECTS FOR THE DEVELOPMENT OF THE DIGITAL ECONOMY IN UKRAINE
}

\author{
Maltuz V.V., Terentieva N.V. \\ Zaporizhzhya National University \\ Ukraine, 69000, Zaporizhzhia, Zhukovsky St. 66 \\ javiktorija@rambler.ru, terenteva_nataliya@ukr.net \\ ORCID: 0000-0002-3863-6456, ORCID: 0000-0001-6930-879X
}

Key words:

digitalization, digitalization, digital economy, digital technologies, marketing, automation, remote control, communications, business processes, computerization.
The article is devoted to the study of the formation of promising mechanisms for the development of the digital economy, substantiation of the process of business digitalization, determination of the main goals of the implementation of digital development in Ukraine. The article investigates the number of enterprises that used computers and the average number of employees who used computers, by type of economic activity and with distribution by the average number of employees, the number of enterprises that had access to the Internet for types of economic activity. The influence of information, communication and digital technologies and means on the management of economic development is determined, the place of digitalization in modern management conditions is determined. A system for improving the process of digitalization of business has been formed.

\section{ПЕРСПЕКТИВИ РОЗВИТКУ ЦИФРОВОЇ ЕКОНОМІКИ В УКРАЇНІ}

\author{
Малтиз В.В., Терент'єва Н.В. \\ Запорізький національний університет \\ Украӥна, 69000, м. Запоріжжя, вул. Жуковського 66
}

\author{
Ключові слова: \\ цифровізація, діджиталізація, \\ цифрова економіка, цифрові \\ технології, маркетинг, \\ автоматизація, дистанційне \\ управління, комунікації, \\ бізнес-процеси, \\ комп'ютеризація.
}

Стаття присвячена дослідженню питань формування перспективних механізмів розвитку цифрової економіки, обгрунтування процесу цифровізації бізнесу, визначення головних цілей реалізації цифрового розвитку в Україні. В статті досліджено кількість підприємств, які використовували комп'ютери, та середня кількість працівників, які використовували комп'ютери, за видами економічної діяльності та з розподілом за середньою кількістю працівників, кількість підприємств, які мали доступ до мережі Інтернет за видами економічної діяльності. Визначено вплив інформаційно-комунікаційних та цифрових технологій і засобів на управління розвитком економіки, визначено місце цифровізації в сучасних умовах управління. Сформовано систему удосконалення процесу цифровізації бізнесу.

\section{Statement of the problem}

Today, Ukraine accepts the importance of a digital economy at the state level, and digital technologies are considered as one of the key drivers of sustainable development. At the same time, the development of the digital economy raises many issues of state regional policy, which must not only be clearly addressed, but also must be solved systematically.

One of such issues is the formation of perspective mechanisms for the development of the digital economy, substantiation of the process of business digitalization, determination of the main goals of digital development in Ukraine. For modern enterprises, which today are forced to work in limited conditions, due to the influence of external factors and digitalize their business, it is extremely important to solve the issues mentioned above.

\section{Analysis of recent studies and publications}

Analyzing the papers of scientists and economists considering theoretical aspects of the digital economy, it should be mentioned that this term was first explored by Don Tapscott and Nicholas Negropont in their articles. D. Bell, F. Mahlupp, D. Kelly studied the prospects for the development of modern economic models of countries that contribute to the formation of the digital economy.

The results of the analysis of domestic publications give the impression that Ukrainian scientists are also actively exploring applied aspects of digital economy development, stages of business digitalization, digitalization in the modern management system, new opportunities and problems of innovation and professional mobility, etc.

Among the domestic sciences should be highlighted the following: Kraus N., Goloborodko O., Fostolovich V., Pankova O., Ishchenko, O., Gorodyanskaya L., Lychkovskaya, M., Medzhidova V.

But despite the sufficient number of publications, there are still many issues that need to be clarified and researched in the process of digitalization and development of the digital economy in Ukraine. 


\section{Objectives of the article}

The aim of the article is to determine the prospects for the development of the digital economy in Ukraine, to study the situation at the modern enterprises taking into account modern economic conditions, the transition to the digital economy and to formulate proposals on how to improve the process of business digitalization.

The main material of the research

Digital technologies are becoming the foundation for the development of new products, values, properties and, consequently, the basis for gaining competitive advantage in most markets. Digitization gives the opportunity for small companies and project teams to create new products and quickly bring them to market along with the large companies which are already present there. Digital transformation leads to the emergence of new unique systems and processes that make up their new value essence.

The main purpose of digitalization is to encourage the consumption and use of digital technologies. That is, to make technology available to business owners and citizens, so that businesses use digital instead of the physical (traditional) tools and instruments, realizing their benefits. This goal has been partially achieved, but the pace of digitization has been affected not only by scientific and technological progress, but also, to a greater extent, by the constraints created by the pandemic.

The examination of the state of digital entrepreneurship and opportunities for the human resources realization in the context of digitalization of the economy shows the contradiction and inconsistency of the state in achieving the main goals and its support for the implementation of measures in this direction.
The digitalization of the economy and society depends on the level of the country development, the quality and number of IT professionals. One of the characteristic features of the digital age is the emergence of a large amount of information that must not only be stored but also analyzed. It is well known that about $90 \%$ of information in digital form has appeared in recent years. Accordingly, the number of enterprises that use computers is growing, as well as the number of labor resources (employees) that know how to use them. Table 2 provides information on the number of enterprises that used computers and the average number of employees who used computers, by type of economic activity and with a distribution by the average number of employees in 2018-2019.

After analizing Table 1, we receive the information that the most digitalized in 2018 were enterprises in the following industries: water supply, sewerage, waste management and repair of computers and communications equipment. Instead, the situation changed in 2019 and the most digitalized in 2019 were enterprises in the following industries: water supply, sewerage, waste management and supply of electricity, gas, steam and air conditioning.

The change of management paradigm in the direction of digitalization places new demands on the employees of enterprises, which are also related to the emergence of new professions, the necessety to learn new competencies, acquire new knowledge that will determine employee productivity and its importance for enterprise development. One of the important characteristics of new knowledge is digital competence. As for the number of employees who use computers, there is a completely different redistribution, namely: in 2018, the industries where employees had high computer skills were professional

Table 1 - Number of enterprises that used computers and average number of employees that used computers, by type of economic activity and by distribution according to the average number of employees in 2018-2019

\begin{tabular}{|c|c|c|c|c|c|c|c|c|}
\hline & \multicolumn{4}{|c|}{$\begin{array}{l}\text { Number of enterprises } \\
\text { that used computers }\end{array}$} & \multicolumn{4}{|c|}{$\begin{array}{l}\text { The average number of employees } \\
\text { who used computers }\end{array}$} \\
\hline & \multicolumn{2}{|c|}{ units } & \multicolumn{2}{|c|}{$\%$} & \multicolumn{2}{|c|}{ people } & \multicolumn{2}{|c|}{$\%$} \\
\hline & 2018 & 2019 & 2018 & 2019 & 2018 & 2019 & 2018 & 2019 \\
\hline Total amount & 44133 & 44532 & 89,7 & 87,9 & 1289828 & 1317214 & 32,8 & 34,3 \\
\hline Processing industry & 11089 & 11279 & 91,7 & 91,0 & 356619 & 350872 & 26,8 & 27,1 \\
\hline $\begin{array}{c}\text { Supply of electricity, gas, } \\
\text { steam and air conditioning }\end{array}$ & 706 & 714 & 93,9 & 93,0 & 82312 & 83981 & 32,9 & 35,0 \\
\hline Water supply; sewerage, waste management & 1147 & 1152 & 95,2 & 93,6 & 22921 & 24091 & 19,5 & 20,7 \\
\hline Construction & 4871 & 4971 & 89,5 & 85,4 & 49591 & 52065 & 25,5 & 25,6 \\
\hline $\begin{array}{l}\text { Wholesale and retail trade; repair of motor } \\
\text { vehicles and motorcycles }\end{array}$ & 10912 & 10889 & 89,3 & 87,3 & 385356 & 394480 & 48,7 & 49,5 \\
\hline $\begin{array}{l}\text { Transport, warehousing, postal } \\
\text { and courier activities }\end{array}$ & 3542 & 3626 & 89,9 & 89,7 & 115251 & 148518 & 17,8 & 24,3 \\
\hline Temporary accommodation and catering & 1312 & 1286 & 83,5 & 78,8 & 18275 & 17742 & 24,1 & 23,4 \\
\hline Information and telecommunications & 1962 & 1961 & 90,6 & 89,9 & 96236 & 76029 & 78,7 & 78,6 \\
\hline Real estate transactions & 2787 & 2763 & 90,5 & 88,4 & 27147 & 26373 & 31,9 & 31,9 \\
\hline $\begin{array}{l}\text { Professional, scientific and technical } \\
\text { activities }\end{array}$ & 2688 & 2729 & 90,2 & 88,6 & 88153 & 90122 & 69,2 & 67,5 \\
\hline $\begin{array}{l}\text { Activities in the field of administrative } \\
\text { and support services }\end{array}$ & 3052 & 3103 & 83,0 & 80,2 & 46426 & 51640 & 24,7 & 27,2 \\
\hline $\begin{array}{c}\text { Repair of computers } \\
\text { and communication equipment }\end{array}$ & 65 & 59 & 95,6 & 88,1 & 1541 & 1301 & 80,0 & 77,3 \\
\hline
\end{tabular}


scientific and technical activities, as well as repair of computers and communications equipment. At the same time, in 2019, these are enterprises such as: repair of computers and communications equipment, information and telecommunications.

The demand for IT professionals continues to exceed the supply worldwide. Today, there is a need for trained IT professionals who will help to improve business processes in companies and improve the quality of their products and services.

In Germany, for example, there is a growing need to improve the skills of existing staff. Surveys conducted there indicate that 49 percent of the surveyed firms were engaged in the search for employees with digital competencies, 53\% will undertake retraining of staff. Experts note that "without digitally competent employees, digitalization will not work".

The introduction of digital technologies at the enterprises has a number of advantages, in particular:

- technologies allow to automate most of the employee's work, freeing up human resources for information retrieval, business communication, staff training;

- digital technologies allow to intensify work, increase its speed and quality, increase productivity;

- digital technologies are able to motivate the employee to be more responsible in the learning process and develop their professional skills.

There is also a positive trend in the number of companies that had specialists in the field of computer technology. Thus, in 2018 their number reached 10,973 people, which is almost 3\% more than in 2017 . It should be added that almost 2,000 companies conducted training courses in the field of computer technology, and more than 3,000 companies recruited specialists in this field.

Information on the number of enterprises that used computers is incomplete, if we do not analyze the number of enterprises that had access to the Internet in 2018-2019. This information is shown in table 2.

The analysis of Table 2.2 reveals a decrease in the number of enterprises that had access to the Internet in 2018-2019.
This result is negative, because today's globalized world requires inclusion in the global informational network. Instead, the data in Table 2.3 show a reduction in the number of enterprises that had access to the Internet for all activities. The exception was such activities as "Transport, warehousing, postal and courier activities". This is due to the rapid development of transport and logistics centers and the development of postal and courier services.

It should be emphasized that the digital economy is currently the leading trend in the labor market. The ability to use digital technologies in work is gradually becoming essential for most specializations and professions.

Through the use of online and other technologies, society can more effectively acquire knowledge, skills and abilities in many areas without leaving home or office, and because the new labor legislation is based on digitalization this topic is extremely timely and relevant today, as the world has a number of limitations to the business processes created by the pandemic.

With regard to the recent events, the Concept of Development of the Digital Economy and Society of Ukraine is gaining popularity. The development of Ukraine's digital economy in accordance with the Concept includes [4]:

- creating market incentives,

- creating motivations,

- analysis and creating demand for the use of digital technologies, products and services (among the Ukrainian sectors of industry, life, business and society) to ensure their efficiency, competitiveness, national development and growth of high-tech products and welfare [4].

The concept suggests to implement a number of measures in order to:

- strengthen the process of digitalization of the economy, public and social spheres;

- raise awareness of existing challenges and tools aimed at developing digital infrastructures;

- to acquire digital competencies by all segments of society;

Table 2 - Number of enterprises that had access to the Internet by type of economic activity in 2018-2019

\begin{tabular}{|c|c|c|c|c|c|}
\hline \multirow{2}{*}{} & \multicolumn{2}{|c|}{ units } & \multicolumn{2}{c|}{$\begin{array}{c}\text { o to the total amount } \\
\text { of enterprises }\end{array}$} & change \\
\cline { 2 - 6 } & $\mathbf{2 0 1 8}$ & $\mathbf{2 0 1 9}$ & $\mathbf{2 0 1 8}$ & $\mathbf{2 0 1 9}$ & \\
\hline Total amount & 43303 & 43785 & 88,0 & 86,4 & - \\
\hline Processing industry & 10878 & 11089 & 90,0 & 89,5 & - \\
\hline Supply of electricity, gas, steam and air conditioning & 701 & 709 & 93,2 & 92,3 & - \\
\hline Water supply; sewerage, waste management & 1130 & 1138 & 93,8 & 92,4 & - \\
\hline Construction & 4783 & 4883 & 87,9 & 83,9 & - \\
\hline Wholesale and retail trade; repair of motor vehicles and motorcycles & 10759 & 10742 & 88,1 & 86,1 & - \\
\hline Transport, warehousing, postal and courier activities & 3462 & 3553 & 87,8 & 87,9 & + \\
\hline Temporary accommodation and catering & 1279 & 1261 & 81,4 & 77,2 & - \\
\hline Information and telecommunications & 1949 & 1946 & 90,0 & 89,2 & - \\
\hline Real estate transactions & 2704 & 2697 & 87,8 & 86,3 & - \\
\hline Professional, scientific and technical activities & 2636 & 2685 & 88,4 & 87,2 & - \\
\hline Activities in the field of administrative and support services & 2958 & 3024 & 80,4 & 78,2 & - \\
\hline Repair of computers and communication equipment & 64 & 58 & 94,1 & 86,6 & - \\
\hline
\end{tabular}


- identify critical areas and digitization projects;

- provide incentives for the domestic production market;

- expand the use and consumption of digital technologies;

The concept stipulates that the development of the digital economy can be implemented in the following ways:

- through the domestic (national) production market;

- through the use and consumption of information and communication and digital technologies [4].

Based on the above, you can schematically form the stages of development and future prospects of the digital economy in Ukraine (Figure 1)

The application of electronic data by the company's management in the process of making management decisions is an element of the implementation of digitalization. This approach through the generalization of automated information resources aimed at solving a specific problem and making management decisions by developing algorithms for solving problems will increase the efficiency and competitiveness of the enterprise. As stated in the Concept [4]

The formation of a system of state support for the integration of digital technologies in all spheres of business and life of the population will stimulate the development of a modern open information society, which will provide:

- the spread of democracy in the country,

- increasing the level of production productivity through the introduction of innovative technologies,

- economic growth of both enterprises and the country as a whole,

- improving the quality of life of the population. At the state level, the main goals of digital development are formed and presented in the Concept [4].

These goals are summarized and shown schematically in Figure 3.

It should be noted that those sectors of the economy of Ukraine that have switched to the widespread use of digital technologies are characterized by faster growth rates, which are given to them cheaper with maximum quality characteristics. Thus, it is easier, cheaper and more efficient to manage a business, sphere, industry using a digital model of development.

So, today the issues of a digital economy and society development are beyond doubt, and the experience of leading countries and companies around the world confirms this. The main components of the digital economy as the next stage in the formation of a modern model of production, technological and social system based on the results of the fourth industrial revolution are regulation, infrastructure, network security (cybersecurity), training and partnerships to create technology platforms. This is what the function of the state in partnership with business should be aimed at, the implementation of which requires an appropriate investment policy.

Digitalization should include three main directions and include strategic directions, operational activities, implementation of the latest technologies (Figure 4).

In general, in Ukraine, these processes are quite slow and, moreover, with a delay in the adoption to the challenges of global trends in political
Fig. 2. The impact of information and communication and digital technologies and tools on the management of economic development

Source: developed by the author based on [1] $\rightarrow$ Digital technologies

$\rightarrow$ Scientific and technological

$\rightarrow$ Electronic digital means and systems

Information and communication technologies 
action at both the state and regional levels. This requires the development of appropriate strategic documents, in particular, scientists, IT business participants together with representatives of regional authorities should develop strategies and develop individual roadmaps of regions in the direction of digital transformation (digitization) of their economies and achieve key socio-economic indicators.

Considering the opportunities provided by decentralization reforms, at the regional level, special attention should be paid to such issues as: current trends in digital transformation (digitalization) in the region and improving the quality of life as a comfortable environment, building a digital environment in the region, support startups in the digital economy, digital future and regional economic security [6].

Infrastructural development and institutional support for the introduction of digital technologies should be main strategic steps, taken by regional authorities to increase the efficiency of the transition to the digital economy. At the same time, of course, the implementation of each of these strategic steps in a given region must take into account their specifics and peculiarities of development. Depending on this, technological solutions that can be used for the development of information as well as communication infrastructure and measures to stimulate the introduction of specific digital technologies and the development of relevant enterprises in the regions may vary.

Under such conditions, many companies have to seriously rethink the format of their activities in terms of costs using the opportunities of digitalization.

Quarantine and the economic crisis have led to large-scale revenue reductions and, often, the physical inability to provide goods or services. Under such conditions, rent immediately became perhaps the biggest problem, especially for SMEs. An alternative to offices was remote work via the Internet (online conferences, remote accounting and document management, etc.). It should be noted that analyzing the results of the study - about $80 \%$ of enterprises and organizations have made a full or partial transition to remote work. That is, modern enterprises go to a completely new level in their labor relations, which in turn requires a system, control, mechanisms that would help to work effectively and regulate remote management of labor resources [6].

In this regard, there are several obvious issues that need a separate analysis for Ukraine, these issues are aimed at improving the process of digitalization of business in today's conditions (Figure 5).
Thus, the digitalization of business today requires proper management and control, new mechanisms of operation and development systems, as well as human resources that can create, implement and manage modern business processes.

\section{Conclusions}

Summing up the research, it should be pointed out that quarantine and the economic crisis have led to large-scale reductions in revenue and, often, the physical inability to provide goods or services. Under such conditions, rent immediately became perhaps the biggest problem, especially for SMEs. An alternative to offices was remote work via the Internet (online conferences, remote accounting and document management, etc.). It should be mentioned that analyzing the results of the study - about $80 \%$ of enterprises and organizations have made a full or partial transition to remote work. That is, modern enterprises go to a completely new

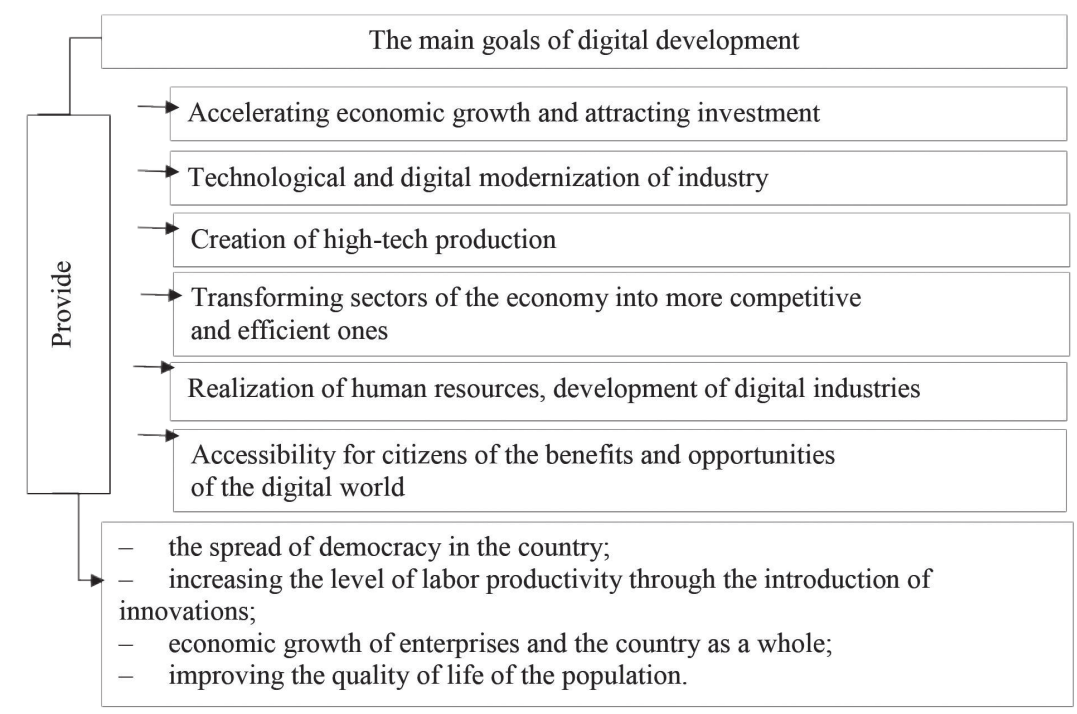

Fig. 3. The main goals of digital development in Ukraine [1]

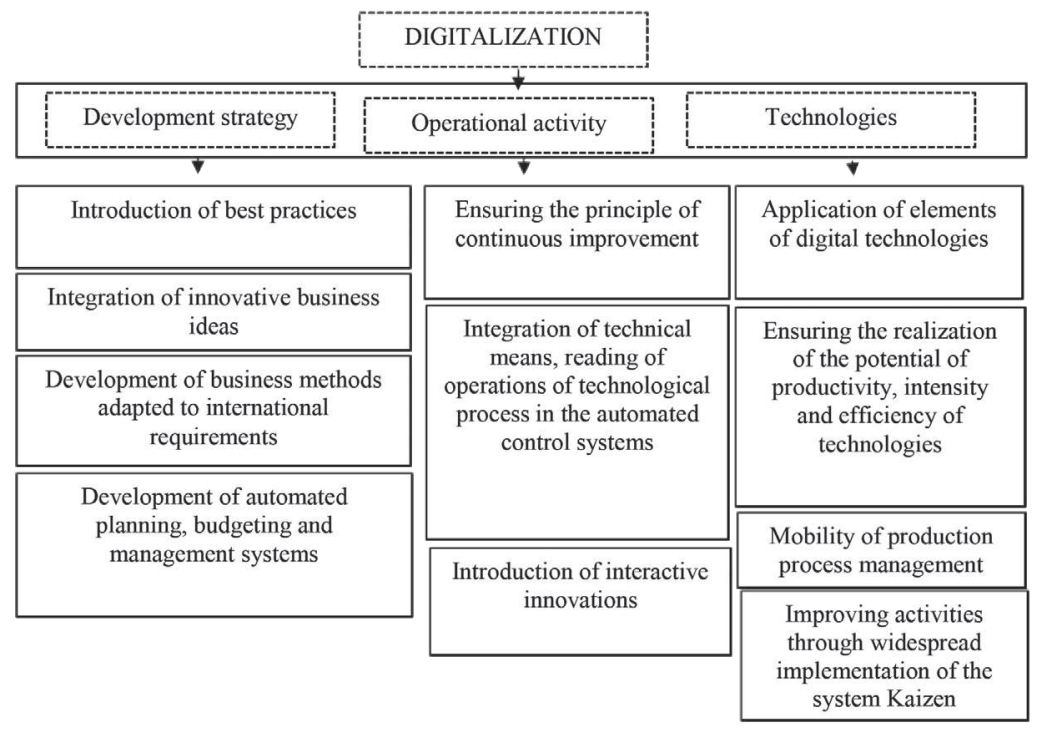

Fig. 4. The place of digitalization in modern management 


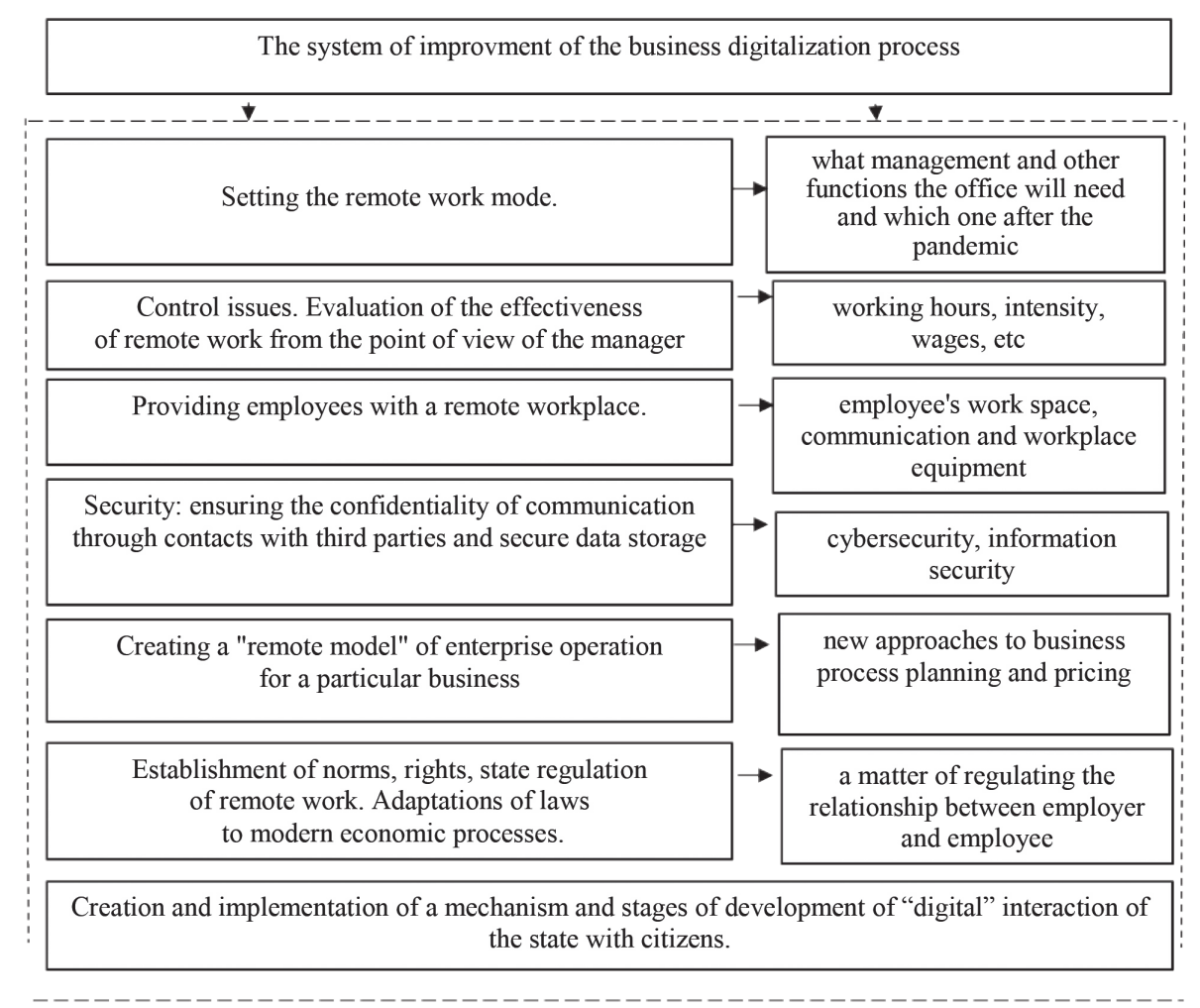

Fig. 5. The system of improvment of the business digitalization process [grouped by authors]

level in their labor relations, which in turn requires a system, control, mechanisms that would help to work effectively and regulate remote management of labor resources.

As a result of the research, a system of improving the process of digitalization of business is proposed, the main direction of which is aimed at implementing the mechanism and stages of development of "digital" interaction of the state with citizens.

Thus, today the issues of developing the digital economy and society in Ukraine are beyond doubt, and the influence of external factors, pandemics and the experience of leading countries and companies in the world confirm this.

\section{References}

1. Kontseptsiia rozvytku tsyfrovoi ekonomiky ta suspilstva Ukrainy na 2018-2020 roky. URL: http://zakon3.rada.gov. ua/laws/show/67-2018-\%D1\%80 (data zvernennia 22.10.2020)

2. Ofitsiinyi sait Derzhavnoi sluzhby statystyky: URL: http://www.ukrstat.gov.ua/ (data zvernennia 01.11.2020)

3. Polyanska, A. S., Kinash I. P., Savchuk P. V. Tsyfrovizatsiia yak chynnyk rozvytku personalu pidpryiemstva. The actual problems of regional economy development. 2.15 (2019): 94-106.

4. Pro skhvalennia Kontseptsii rozvytku tsyfrovoi ekonomiky ta suspilstva Ukrainy na 2018-2020 roky ta zatverdzhennia planu zakhodiv shchodo yii realizatsii: rozporiadzhennia Kabinetu Ministriv Ukrainy vid 17 sichnia 2018 r. № 67-p. URL: https://www.kmu.gov.ua/npas/pro-shvalennya-koncepciyi-rozvitku-cifrovoyiekonomikita-suspilstva-ukrayini -na- 20182020- roki- ta- zatverdzhennya- planu- zahodiv- shodo -уiyirealizaciyi (дата звернення 12.08.2020)

5. Fostolovych V.A., Tsyfrovizatsiia v suchasnii systemi upravlinnia. Ekonomika. Finansy. Menedzhment: aktualni pytannia nauky i praktyky, 2019, № 7 .

6. Ofitsiinyi sait Instytutu ekonomichnykh doslidzhen ta politychnykh konsultatsii URL: http://www.ier.com.ua (data zvernennia 20.10.2020) 